\section{ON THE EARLY TEMPLE AND PYRAMID BUILDERS.}

I HAVE in previous articles discussed the orientation of many temples in various parts of Egypt. It will have been seen that it has been possible to divide them into solar and stellar temples, and that in the case of the former both solstices and equinoxes have been in question.

I have also referred to the very considerable literature which already exists as to the pyramids, and shown how the most carefully constructed among them are invariably oriented truly to the four cardinal points, and further that it is possible that some parts of their structures might have served some astronomical purpose, since astronomical methods must certainly have been employed in their construction.

It has also been suggested that the fundamental difference between solstitial and equinoctial worships indicated by the solstitial temples and the pyramids required nothing less than a difference of race to explain it. I propose now to inquire if there be any considerations which can be utilised to continue the discussion of the question thus raised on purely astronomical grounds. It is obvious that if sufficient tradition exists to permit us to associate the various structtires which have been studied astronomically with definite periods of Egyptian history, a study of the larger outlines of that history will enable us to determine whether or not the critical changes in dynasties and rulers were or were not associated with critical changes in astronomical ideas as revealed by changes in temple-worship. If there be no connection the changes may have been ciue to a change of idea only, and the suggestion of a distinction of race falls to the ground.

In a region of inquiry where the facts are so few and difficult to recognise among a mass of myths and traditions, to say nothing of contradictory assertions by different authors; the more closely we adhere to a rigidly scientific method of inquiry the better. I propose to show, therefore, that there is one working hypothesis which seems to include a great many of the facts, and I hope to give the hypothesis and the facts in such a way that if there be anything inaccurately or incompletely stated it will be easy at once to change the front of the inquiry and proceed along the new line indicated.

I may begin by remarking that it is fundamental for the hypothesis, that the temples of On or Heliopolis, as stated by Maspero and other high authorities, existed before the times of Mini (Menes) and the pyramid builders, whatever may have been the date of the original foundation of Thebes.

Before Mini, according to Maspero, "On et les villes du Nord avaient eu la part principale dans le développement de la civilisation Égyptienne. Les prières et la hymnes, qui formèrent plus tard le noyau des livres sacrés, avaient été ridigés à On."1

The working hypothesis is as follows :-

I. The first civilisation as yet glimpsed in Egypt, represented by On or Heliopolis, was a civilisation with a solstitial solar worship associated with the rise of the Nile. A northern star was also worshipped.

2. Memphis (possibly also Sais, Bubastis, Tanis, and other cities with east and west walls) and the pyramids were built by an invading race from a land where the worship was equinoctial. A star rising in the east was worshipped at the equinox.

3. The blank in Egyptian history between the sixth and eleventh dynasties was associated with conflicts between these races, which were ended by the victory of the representatives of the old worship of On. After them pyramid building ceased and solstitial worship was resuscitated; Memphis takes second place, and Thebes, a southern On, so far as solstitial solar worship is concerned, comes upon the scene as the seat of the twelfth dynasty.

$$
\text { NO } 1229 \text {, VOL. } 48 \text { ] }
$$

4. The subsequent historical events were largely due to conflicts with intruding races. The intruders established themselves in cities with east and west walls, and were on each occasion driven out by solstitial solar worshippers who founded dynasties (eighteenth and twenty-fifth) at Thebes.

$$
\text { I. - On. }
$$

I have taken another occasion of remarking how the various worships at Thebes were reflected in the orientation of the temenos walls. The so-called "symmetrophobia " of the Egyptians was full of meaning, which in this case, at all events, is no longer hidden. If we note this reflection, as we can over and over again, where both temples and walls still stand, it is fair to assume that where the walls alone remain the temples which they once enclosed, long since destroyed, had the same relation. These considerations, alas, have to be appealed to in the case of Heliopolis, to say so far nothing of Abydos and Memphis.

At Heliopolis the so-called "symmetrophobia" as indicated by the trend of the mounds given in Lepsius's plan, is so strong that in spite of the fact that only one obelisk of one temple remains, it is easy to show that both solstitial solar worship and star worship were carried on, if walls had the same relation to the included temples at $\mathrm{On}$ as they had at Thebes.

The solar temple at On has entirely disappeared. As may be gathered from the remains of the mounds, it lay in the line of the solstices. As the gods included Rā, Atmu, and Osiris, probably like the temple of Amen Ra at Thebes there were two temples back to back. At Thebes the temples were directed north-west-south-east, at On south-west-north-east.

My observations of the orientation of the obelisk show that the temple of which it formed part may have possibly been the first of the series which includes the temple of Mut at Thebes, and other temples, there and at Abydos; that is the worship of Set was in question, to speak generically. Now, according to Maspero, ${ }^{1}$ Sit or Set formed one of the divine dynasties, being associated with the sun and air gods at On, i.e. with Rā, Atmu, Osiris, Horus, and Shou.

At Abydos, as also can be determined by the orientation of the walls, one of the oldest temples was probably a solstitial one. The stellar temples sacred to Set were built much later than the solar temple.

Like On, Abydos was a sacred city. ${ }^{2}$

"C'est comme ville sainte qu'elle était universellement connue. Ses sanctuaires etaient célèbress, son dieu Osiris vénéré, ses fêtes suivies par toute l'Egypte; les gens riches des autres nomes tenaient à honneur de se faire dresser une stèle dans son temple." ${ }^{3}$

If it be found that the references to "ancestors," and "divine ancestors," occur after the eleventh dynasty, the race represented by On may be referred to (see the articles on the Egyptian year), and it may be that so often referred to as the Hor schesu.

Only one star temple, as I have said, is still represented at On; those at Abydos are known to be late. The term, then, of Sun-worshippers was highly distinctive, and there is reason to believe that the stellar observations were connected with the solar worship.

$$
\text { 2.-(a) The East and West Walls and Pyramid }
$$

On the hypothesis these came from a country where the worship was equinoctial.

We are justified from what is known regarding the rise of the Nile as dominating and defining the commencement of the Egyptian year that other ancient peoples placed under like conditions would act in the same way.

Now what the Nile was to Egypt the valleys of the

1 op. cit. p. 33 .

2 Maspero, op. cit., p. $2 x$

3 It is important to inquire -if this took place after the advent of the eleventh dynasty. 
Tigris and the Euphrates were to the early Chaldæan empire. Like the Nile, these valleys were subject to annual inundations, and their fertility depended, as in Egypt, upon the manner in which the irrigation was looked after.

But unlike the Nile, the commencement of the inundation of these rivers took place near the vernal equinox; hence the year, we may assume, began then, and, reasoning by analogy, the worship in all probability was equinoctial.

A people entering Egypt from this region, then, would satisfy one condition of the problem, but is there any evidence that this people built their solar temples and temple walls east and west, and that they also built pyramids?

There is ample evidence, although, alas! the structures in Chaldæa, being generally built in brick and not in stone, no longer remain, as do those erected in Egypt. Still, in spite of the absence of the possibility of a comparative study, research has shown that in the whole region to the north-east of Egypt the temenos walls of temples and the walls of towns run east and west; and though at present actual dates cannot be given, a high antiquity is suggested in the case of some of them. Further, the temples which remain in that region where stone was procurable, as at Palmyra, Baalbec, Jerusalem, all lie east and west. But more than this, it is well known that from the very earliest times pyramidal structures, called ziggurats, some 150 feet high, were erected in each important city. These were really observatories; they were pyramids built in steps, as clearly shown from pictures found on contemporary tablets; and one with seven steps and of great antiquity, it is known, was restored by Nebuchadnezzar about 600 B.C. at Babylon. fied.

A second condition of the hypothesis is therefore satis-

But did this equinox-worshipping, pyramid-building race live at anything like the time required? Prof. Sayce showed in the Hibbert lectures which were delivered in the year 1887 that recent finds have established the existence of a King Sargon I. at Agade in Chaldæa 3800 B.C. Hence it seems that a third condition of the hypothesis is satisfied by this recent discovery. There was undoubtedly an equinox-worshipping, pyramid-building race existing in Chaldæa at the time the Egyptian pyramids are supposed to have been built.

Hommel, in a recent paper on the Babylonian origin of Egyptian culture, shows that the names of the gods corresponded in many cases with the names of deities mentioned in the oldest Egyptian pyramid texts. . . . The names were represented by exactly the same signs in both Babylonian and Egyptian hieroglyphics . . . the name and signs of Osiris the Babylonian Asari are represented in both countries by an eye. He contends that there had been a direct communication between the two civilizations, and that the Babylonian was the older of the two.

Next let us return to Egypt.

We find at Memphis, Sais, Bubastis, and Tanis east and west walls which at once stamp those cities as differing in origin from On, Abydos, and Thebes, where, as I have shown, the walls trend either north-west south-east or north-east--south-west.

For Memphis, Sais, and Tanis, the evidence is afforded by the maps of Lepsius. For Bubastis it depends upon the statement of Naville, that the walls run " nearly from east to west," and with the looseness too often associated with such statements, it is not said whether true or magnetic bearings are indicated.

Associated with these east and west walls there is farther evidence of great antiquity. Bubastis, according to Naville, ${ }^{1}$ has afforded traces of the date of Cheops and Chephren, and it is stated by Manetho to have existed as early as the second dynasty.

$$
1 \text { "Bubastis," preface, p. iv. }
$$

No. 1229 , voL. 48$]$
It is also generally known that the pyramids in Egypt are oriented east and west. Nor is this all.

One of the oldest, if not the oldest, pyramid known, is a step pyramid modelled on the zuggurat pattern: the socalled "step pyramid of Sakkarah." The steps are six in number, and vary in height from thirty-eight to twentynine feet, their width being about six feet. The dimensions are ( 352 north and south) $\times(396$ east and west) $x$ 197 feet. Some authorities think this pyramid was erected in the first dynasty by the fourth king (Nenephes of Manetho, Äta of the tablet of Abydos.) The arrangement of chambers in this pyramid is quite special.

The claim to the highest antiquity of the step pyramid is disputed by some in favour of the "false pyramid" of Mêdûm. It also is really a step pyramid I I 5 feet high ; its outline, which conceals some of the steps, shows three stages, seventy, twenty, and twenty-five feet high; but in its internal structure it is really a step pyramid of six stages.

This pyramid must, according to Petrie, be attributed to Seneferu; but De Rouge has given evidence to the contrary. ${ }^{1}$ Seneferu was a king of the fourth dynasty.

We have at Dashour the only remaining abnormal pyramid called the blunted pyramid, for the reason that the inclination changes at about one-third of the height. This pyramid forms one of a group of four, two of stone, and, be it carefully borne in mind, two of brick ; their dimensions are $700 \times 700 \times 326$ feet ; $620 \times 620 \times 321$ feet; $350 \times 350 \times 90$ feet ; and $343 \times 343 \times 156$ feet.

One of these pyramids was formerly supposed to have becn built by Seneferu; if any of them had been erected by King Ousertsen III. of the twelfth dynasty, as was formerly thought, the hypothesis we are considering would have been invalid.

Only after Seneferu, then do we come to the normal Egyptian pyramid, the two largest at Gizeh built by Cheops and Chephren (fourth dynasty) being, so far as is accurately known, the oldest of the series. (According to Mariette the date of Mini is 5004 B.C., and the fourth dynasty commenced in 4235 .)

Associated with the cities with east and west walls are temples facing due east, fit, therefore, to receive the rays of the morning sun rising at an equinox.

Associated with these pyramids carefully oriented east and west, we find on their eastern sides some distance away, and on a line passing through their centres at right angles to a meridian line, temples facing due west, the clearest possible indication of equinoctial worship. At sunset at the equinox the sepulchral chamber and the sun were in line from the adytum. The priest faced a double Osiris.

In the case of the pyramid of Chephren, not only have we, as I hold, such a temple of Osiris, but the Sphinx granite temple was most probably the crypt of a temple of Isis, its relation to the south face of the pyramid being borne in mind. If this were so Osiris was a name both for the solstitial and equinoctial sun.

Other pyramids were built at Sakkarah during the sixth dynasty, but it is remarkable that such a king as Pepi-Meri-Rã should not have imitated the majestic structures of the fourth dynasty. $\mathrm{He}$ is said to have built a pyramid at Sakkareh, but its obscurity is evidence that the pyramid idea was giving way, and it looks as if this dynasty were really on the side of $\mathrm{On},{ }^{2}$ for the authority of Memphis declined, and Abydos was preferred, while abroad Sinai was reconquered, and Ethiopia was kept in order. ${ }^{3}$

The sphinx (oriented true east) must also be ascribed to the earliest pyramid builders; it could not have been built before their intrusion. The Colossi of the plain at

1 Maspero, op. cit. p. 59.2 Maspero, op. it. p. 80.

3 Further, it is known that there was some conne ztion between Pepi-Meri$\mathrm{R} \bar{a}$ and the eleventh dynasty of Thebes. Maspero, op. cit. p. $9 \mathrm{I}$. 
Thebes was a subsequent reply of the On solstitial worship to it.

\section{(b) The Worship of the Bull by the Pyramid Builders.}

There is a subsidiary point in connection with the pyramid builders and equinoctial worship.

The worship of Apis preceded the building of pyramids. Mini is credited by Elian with its introduction, ${ }^{1}$ but at any rate Kakau of the second dynasty issued proclamations regarding it, ${ }^{2}$ and a statue of Hapi was in the temple of Cheops. ${ }^{3}$

It is stated that the first month of the Chaldæan year was dedicated to the "propitious bull," and that the figure of a bull constantly occurs on the monuments as opening the year. Now the sun at the vernal equinox 4500 B.C. was in the constellation Taurus. Biot has shown that the equinox occurred with the sun near the pleiades in 3285 B.C. We seem driven to the conclusion that the constellation of the bull dates from this time, and that Hapi represented it. ${ }^{4}$

\section{(c) The Art of the Pyramid Builders.}

Another connecting link is found in the diorite statues found in the temple of Chephren, at the pyramids, and at Tell-loh (ancient Sirgalla) by M. de Sarzec in $\mathbf{1} 881$.

This last find consisted of some large statues of diorite, and the attitude chosen was that of Chephren himself as represented in the Museum of Gizeh.

This indicates equality in the arts and the possession of similar tools in Chaldæa and Egypt about the time in question.

\section{(d) The Star Worship of the Pyramid Builders.}

I have given before the gods of Heliopolis, and have shown that with the exception of Sit none are stellar; and that the temple of Sit is still represented. But we find in pyramid times the list is vastly changed; only the Sun gods Ra, Horus, Osiris, are common to the two. As new divinities we find ${ }^{5}:-$

Isis.
Hathor.
Nephthys.
Ptah.
Selkit.
Sokhit.

Of these the first two and the last two undoubtedly symbolised stars, and there can be no question that the temple of Isis at the pyramids was built to watch the rising of some of them. ${ }^{6}$ Of Iris and. Hathor I have already written at length, and I think the stars are now known. The others are more doubtful, but it may be that Ptah $=$ Capella and Selkit $=$ Antares.

But it is also stated that at Memphis ${ }^{7}$ [time not given] there were temples dedicated to Soutekh and Baal. Now this is of great importance, for I suppose there is now no question among Egyptologists that the gods Set, Sit, Typhon, Bes, Soutekh, Soutkhou are identical. It is also equally well known that Soutekh was a god of the Canaanites ${ }^{8}$ that the hippopotamus, the emblem of Set and Typhon, was the hieroglyph of the Babylonian god Baal, ${ }^{9}$ and Bes is identified with Set in the book of the dead. ${ }^{10}$

Maspero, op. ci... p. 44, note.

2 Maspero, op. cit. p. 46.

Maspero, op. cii. p. 64 .
4 Not only the bull; there is evidence in favour of the view that the goddess Selk $=$ Aritares. If so, the scorpion constellation had also been established, and both equinoxes marked by constellations in the time of Cheops. Maspero, op. cit. p. 64 .

6 The temple of Saïs, as I have said, had east and west walls, and so had Memphis, according to Lepsius. The form of Isis at Sais was the goddess Neith, which, according to some authorities, was the precursor of Athene. The temple of Athene at Athens was oriented to the Pleiades.

7 Maspero, op. cit. p. 357.

9 Pierret, p. 4.

10 Idem, p. $4^{8 .}$
Jensen in his "Kosmologie der Babylonier," p. I6, points out that Bil was the name for the pole of the equator. If this be the Baal referred to by Pierret, we get the most marvellous coincidence between the Egyptian and Babylonian star-worship and suggestion of a common origin among an astronomically-minded people.

This suggests that the founders of On and Memphis had a common origin, and the Memphitic intrusion took place after solar solstitial worship had been introduced at On. This worship could not have been brought into Egypt from any other country, bordering on Chaldæa, and its ultimate predominance is the origin of the myth of Horus slaying the hippopotamus. Nay, it may be also suggested that the predominance was brought about by men and ideas reaching On from the south, so that the myth had a single celestial and a double terrestrial side.

The Hawk God of Edfû, Harhouditi, had for servants a number of individuals called Masniou or Masnitiou= blacksmiths, just as the Hawk God of the Delta, Harsiisit, has for his entourage the Shosou Horou. Maspero in a most interesting paper ${ }^{1}$ has recently called attention to some customs still extant among the castes of blacksmiths in Central Africa, which have suggested to him that the followers of the Edfû Horus may have come from that province.

He writes : "C'est du sud de l'Égypte que les forgerons sont remontés vers le nord, leur siège primitif était le sud de l'Égypte, la partie du pays qui a le plus des rapports avec les régions centrales de l'Afrique et leurs habitants.'

Then after stating the present conditions of these workers in equatorial Africa, where they enjoy a high distinction, he concludes :-

"Je pense qu'on peut se représenter l'Horus d'Edfou comme étant au début, dans l'une de ses formes, le chef et le dieu d'une tribu d'ouvriers travaillant le métal, ou plutôt travaillant le fer. On ne saurait en effet se dissimuler qu'il y a une affinité réelle entre le fer et la personne d'Horus en certains mythes. Horus est la face céleste (horou), le ciel, le firmament, et ce firmament est de toute antiquité, un toit de fer, si bien que le fer en prit le nom de ba-ni-pit, métal du ciel, métal dont est formé le ciel : Horus l'aîné, Horus d'Edfou, est donc en réalité un dieu de fer. Il est, de plus, muni de la pique ou de la javeline à point de fer, et les dieux qui lui sont apparentés, Anhouri, Shou, sont de piquiers comme lui, au contraire des dieux du nord de l'Égypte, Ra, Phtah, etc., qui n'ont pas d'armes à l'ordinaire. La légende d'Harhouditi conquérant l'Égypte avec. les masniou serait-elle donc l'écho ointain d'un fait qui se serait passé au temps antérieurs à l'histoire? Quelque chose comme l'arrivée des Espagnols au milieu des populations du Nouveau Monde, l'irruption en Égypte de tribus connaissant et employant le fer, ayant parmi elles une caste de forgerons et apportant le culte d'un dieu belliqueux qui aurait été un Horus ou se serait confondu avec l'Horus des premiers Egyptiens pour former Harhouditi. Ces tribus auraient été nécessairement d'origine Africaine et auraient apporté de nouveaux éléments Africains à ceux que renfermait déjà la civilisation du bas Nil. Les forgerons auraient perdu peu à peu leurs privilèges pour se fondre au reste de la population: à Edfou seulement et dans les villes où l'on pratiquait le culte de l'Horus d'Edfou, ils auraient conservé un caractère sacré et se seraient transformés en un sorte de domesticité religieuse, les masniou du mythe d'Horus, compagnons et serviteurs du dieu guerrier."

\section{3.-The Work of the Eleventh and Twelfth Dynasties.}

We have next to consider what happened after the great gap in Egyptian history between the sixth and twelfth dynasties, 3500 B.C. -285 I B.C. (Mariette), from

\footnotetext{
$1 L^{\prime}$ Anthropologie, July-August, 1891, No. 4.
}

No. I 229 , voL. 48 ] 
Nitocris to Amenemhat $I$. We pass to the Middle Empire.

Amenemhat I. built no pyramids, he added no embellishments to Memphis; but he took Heliopolis under his care, and now we first hear of Thebes. ${ }^{1}$

Usertsen I. built no pyramids, he added no embellishments to Memphis, but he also took Heliopolis under his care, and added obelisks to the temples, one of which remains to this day. Further, he restored the temple of Osiris at Abydos, and added to the temple of Amen-Rā at Thebes. ${ }^{2}$

Surely it is very noteworthy that the first thing the kings of the twelfth dynasty did was to look after the only three temples in Egypt of which traces exist, which I have shown to have been oriented to the solstice.

It is right, however, to remark that there seems to have been a mild recrudescence of pyramid building towards the end of the twelfth dynasty, and immediately preceding the Hyksos period, whether as a precursor of that period or not.

Usertsen's views about his last home have come down to us in a writing by his scribe Mirri : ${ }^{3}$

"Mon maître m'envoya en mission pour lui préparer une grande demeure éternelle. Les couloirs et la chamhre intérieure étaient en maçonnerie et renouvelaient les merveilles de construction des dieux. Il y eut en elle des colonnes, sculptées, belles comme le ciel, un bassin crasusé qui communiquait avec le Nil, des portes, des obélisques, une façade en pierre de Rouou."

There was nothing pyramidal about this idea, but I 50 years later we find Amenemhat III. returning both to the gigantic irrigation works and the pyramid building of the earlier dynasties.

The scene of these labours was the Fayyum, where, to crown the new work, two ornamental pyramids were built, surmounted by statues, and finally the king himself was buried in a pyramid near the Labyrinth.

\section{4.-The Work of the Eighteenth Dynasty.}

The blank in Egyptian history between the twelfth and eighteenth dynasties is known to have been associated with the intrusion of the so-called Hyksos. It is supposed these made their way into Egypt from the countries in and to the west of Mesopotamia. It is known that they settled in the cities with east and west walls. They were finally driven out by Aahmes, the king of solstitial solar Thebes, who began the eighteenth dynasty.

In (a) I have shown what happened after the first great break in Egyptian history - a resuscitation of the solstitial worship at On, Abydos and Thebes.

I have next to show that precisely the same thing happened after the Hyksos period (Dyn. 13 (?) Mariette, 2233 Brugsch; Dyn. I 8, I703 B.C., Mariette) had disturbed history for some 500 years.

It is known from the papyrus Sellier (G.C. 25\%) that Aanhmes, the first king of the eighteenth dynasty, who reestablished the independence of Egypt, was in reality fighting the priests of Soutekh in favour of the priests of Amen R $\vec{a}$, the solstitial solar god, a modern representative of Atmu of On.

Amen-Ra was the successor of Menthu, the successor of Atmu of On. So close was the new worship to the oldest at On, that at the highest point of Theban power the third priest of Amen took the same titles as the Grand Priest of On, "who was the head of the first priesthood in Egypt." " The "Grand Priest of On," who was also called the "Great Observer of Rā and Atmu," had the privilege of entering at all times into the Habenben or Naos. The priest Padouamen, whose mummy was found in $189 \mathrm{I}$, bore these among his other titles.

\footnotetext{
$\begin{array}{ll}1 \text { Maspero, op. cit., p. I12. } & 2 \text { Maspern, op. cit. p. Irz. } \\ 3 \text { Maspero, } o p \text {. cit. p. זा3. } & 4 \text { Virey, New Gizeh Catalogue, p. } 263 .\end{array}$ NO. I 229 , VOL. 48 ]
}

The assumption of the title was not only to associate the Theban priesthood with their northern confrères, but surely to proclaim that the old On worship was completely restored.

\section{5.-The Work of the Twenty-fift/ Dynasty.}

There was another invasion from Syria, which founded the twenty-second dynasty, and again the government is carried on in cities with east and west walls (Sais, Tanis, and Bubastis). The solstitial solar priests of Thebes withdraw to Ethiopia. They return, however in 700 B.C. drive out the Syrian invaders, and, under Shabaka and Taharga, found a dynasty (the twenty-fifth) at Thebes, and embellish the solstitial solar temples there.

\section{6.-Anthropological Evidence.}

It will be seen then that a general survey of Eyyptian history does suggest conflict between two races, and this of course goes to strengthen the view that the temple building phenomena suggest two different worships, depending upon race distinctions.

We have next to ask if there is any anthropological evidence at our disposal. It so happens that Virchow has directed his attention to this very point. ${ }^{1}$

Premising that a strong race distinction is recognised between peoples having brachycephalic or short, and dolicocepllalic or long, skulls, and that the African races belong to the latter group, I may give the following extract from his paper :-

"The craniological type in the Ancient Empire was different from that in the middle and new. The skulls from the Ancient Empire are brachycephalic, those from the new and of the present day are either dolichocephalic or mesaticephalic; the difference is therefore at least as great as that between the dolichocephalic skulls of the Frankish graves and the predominantly brachycephalic skulls of the present population of South Germany. I do not deny that we have hitherto had at our disposal only a very limited number of skulls from the Ancient Empire, which have been certainly determined; that therefore the question whether the brachycephalic skull-type deduced from these was the general or at least the predominant one cannot yet be answered with certainty, but I may appeal to the fact that the sculptors of the Ancient Empire made the brachycephalic type the basis of their works of art too."

It will be seen, then, that the anthropological as well as the historical evidence runs on all fours with the results to be obtained from such a study of the old astronomy as the temples afford us.

\section{J. NORMAN LOCKYER.}

\section{NOTES.}

ON Monday, May 29, the Duke of Connaught will open the new engineering and electrical laboratories at University College, London.

A GENERAL meeting of the members of the Federated Institution of Mining Engineers will be held in the rooms of the Institution of Civil Engineers, 25, Great George Street, Westminster, on Thursday, June I, at 12 noon, and on Friday, June 2, at 10 a.m.

Tне Niederrheinische Gesellschaft fïr Natur- und Heilkunden at Bonn, proposes to celebrate its seventy-fifth anniversary on July 2. A scientific meeting will be held in the forenoon in the music hall of the University of Bonn, and at one o'clock the members will dine together at the hotel "Zum Goldenen Stern." In the afternoon there will be an excursion to Rüngsdorf.

1 Prof. R. Virchow : "Land und Leute im alten und neuen Aegypten:" Verhandlungen der Gesellschaft fïr Erdkunde zh Berlin, pp. 434-436, Band xv. No. 9 . 